\title{
PENERJEMAHAN METAFORA DALAM SAMAN KE DALAM BAHASA PRANCIS
}

\author{
Prasuri Kuswarini \\ Masdiana \\ Zulvyati Hantik \\ Departemen Sastra Prancis, Fakultas Ilmu Budaya, Universitas Hasanuddin \\ p.kuswarini@ fib.unhas.ac.id \\ masdiana@fs.unhas.ac.id \\ zulvyatihantik@gmail.com

\begin{abstract}
Ayu Utami's novel Saman used many metaphors to express the messages to be conveyed. These metaphors are formed in various ways. Translation as a means of relaying the ST message into the TT must be able to transfer the messages that the metaphors convey equally. This article contains the result of research on the methods used to translate the metaphor in the Indonesian version of the Saman novel to the French version. The first phase of analysis was to make a classification of metaphor types in Saman of the Indonesian version. The second step, was to analyze the method used in translating the metaphor found in the French version of the novel. The results show that there are some unusual metaphors in the source language (SL). In general, the metaphor translated in French used literal methods of translation. Some translation errors are also found
\end{abstract}

Keywords: Metaphors, Translation, Messages, Saman, Ayu Utami

\section{A. Latar Belakang}

Karya sastra seringkali identik dengan penggunaan berbagai macam gaya bahasa. Tujuannya antara lain untuk memberikan efek estetis. Salah satu gaya bahasa yang sering digunakan dalam karya sastra adalah metafora. Metafora berasal dari bahasa latin yang kemudian diadaptasi oleh bahasa Yunani yang artinya memindahkan sebuah kata ke dalam ungkapan bahasa figuratif (dalam Glueck, 1993:388). Selain aspek estetika, metafora juga merupakan cara untuk memperkuat gambaran tokoh, latar, dan peristiwa. Kekuatan metafora tersebut dapat mempengaruhi imajinasi dan emosi pembaca.

Metafora adalah konstruksi bahasa yang banyak dipengaruhi oleh budaya setempat. Namun, selain budaya, metafora dalam karya sastra juga seringkali merupakan kreatifitas pengarang. Meskipun demikian, konstruksi metafora hasil kreatifitas pengarang tetap berpatokan pada aturan pembentukan metafora yang berlaku.

Karya sastra yang baik biasanya sarat pesan dan makna. Metafora adalah salah satu alat untuk menyampaikan pesan tersebut. Oleh karena itu, penerjemahan karya sastra sebaiknya memperhatikan metafora-metafora yang digunakan, agar dapat mengalihkan pesan yang dikandung sebuah karya secara sepadan.

Penerjemahan adalah sebuah upaya untuk memindahkan pesan dari bahasa sumber (BSu) ke bahasa sasaran (BSa) sesepadan mungkin (Hoed, 1993:1). Untuk mencapai kesepadanan, penerjemah harus bekerja mulai dari tataran sintaksis hingga semantis. Sebagai 
contoh, untuk menerjemahkan sebuah metafora, yang harus pertama diperhatikan adalah konstruksi sintaksisnya, baru kemudian dicari padanan semantisnya. Bila metafora yang ditemukan berasal dari budaya, sebaiknya dicarikan padanannya dalam budaya BSa. Kesepadanan penerjemahan metafora sangat dianjurkan agar ekspresi pengarang untuk mempengaruhi imajinasi dan emosi pembaca, dapat ditangkap secara maksimal oleh pembaca BSa.

Novel Saman karya Ayu Utami meraih penghargaan sastra yang cukup bergengsi di Indonesia. Novel ini berisi kritik terhadap pemerintah rezim Orde Baru yang memperlakukan orang-orang yang kritis sebagai musuh. Selain itu, novel ini juga mencerminkan perubahan nilai moral yang ada di masyarakat Indonesia.

Kekuatan novel Saman antara lain terletak pada gaya bahasanya. Metafora adalah salah satu gaya bahasa yang dominan digunakan dalam novel tersebut. Novel ini telah diterjemahkan ke dalam beberapa bahasa, salah satunya bahasa Prancis. Artikel ini membahas, bagaimana metafora-metafora dalam Saman diterjemahkan ke dalam Bahasa Prancis.

\section{B. Landasan Teori}

\section{- Metafora}

Secara historis, Aristoteles merupakan tokoh yang pertama kali mencetuskan dan membahas metafora dalam kaitannya dengan dua bidang yaitu retorika dan puisi. Metafora di sini digunakan sebagai sebuah alat (organon). Retorika merupakan gaya bahasa yang digunakan untuk mempengaruhi dan mengubah pandangan atau pola pikir seseorang (rhetoric-proofpersuasion), dan metafora di sini berfungsi sebagai alat untuk mempersuasi. Di dalam puisi, metafora digunakan untuk menggambarkan sebuah kenyataan dengan cara mimetik atau meniru sebuah kenyataan lain. Mimesis dalam puisi dilakukan untuk tujuan memproduksi rasa tertentu (emotive value) pada orang-orang yang mendengarkan (poiêsis- mimésis-catharsis, dalam Wahyuddin, 2012:1). Dalam Kamus Besar Bahasa Indonesia, metafora adalah pemakaian kata atau kelompok kata bukan dengan arti yang sebenarnya, melainkan sebagai lukisan yang berdasarkan persamaan atau perbandingan, misalnya: pemuda adalah tulang punggung negara. Secara semiotis, metafora (Hasyim, 2017: 524) adalah a way of conceptualizing or relating a sign (topic) to another entity through the use of analogy (differentiations or equations). Metaphor works by employing two signs, i.e., the first serves as the source or domain (topic) and the second serves as the target (vehicle), which give birth to a new meaning (grounds).

Aristoteles dalam Poetika membagi metafora secara formal berdasarkan hubungan antara kandungan bentuk pengganti dengan bentuk yang diganti. Metafora mensyaratkan adanya kemiripan atau kedekatan asosiatif antara dua ungkapan, yang bisa digantikan oleh sebuah kata pengganti (verbum proprium). Meski metafora menghasilkan efek lain, yaitu konotasi yang menyertai manusia, hewan atau kejadian yang diwakilinya, pemahamannya tetap berdasarkan pada konvensi (dalam Glueck, 1993:388).

Pengelompokan metafora oleh Aristoteles berdasarkan kriteria semantis: makhluk hidup dan benda mati (dalam Glueck, 1993:388).

a. Makhluk hidup menggantikan makhluk hidup

b. Benda mati menggantikan benda mati

c. Makhluk hidup menggantikan benda mati

d. Benda mati menggantikan makhluk mati Stephen Ullman membagi metafora kedalam 4 kelompok (dalam Parera, 2004: 120):
a. Antrhomorphic
metaphors, yaitu membandingkan
kemiripan 
pengalaman yang terjadi pada tubuh seseorang, contohnya: mulut botol, jantung kota, bahu jalan, dst.

b. Animal metaphors membandingkan satu kondisi atau kenyataan dengan binatang, atau tanaman, contohnya: kumis kucing, lidah buaya, kuping gajah.

c. From concrete to abstract ialah mengalihkan ungkapan-ungkapan yang abstrak ke ungkapan yang lebih kongkret, misalnya: cepat seperti kilat:

d. Synaesthetic metaphors, adalah pengalihan dari satu indra ke indra yang lain, contohnya: music yang "enak didengar", sedap dipandang mata, dll.

\section{- Teori Penerjemahan}

Sebagai perantara dalam proses komunikasi, penerjemahan (Hoed, 1993:1) bertujuan memperoleh padanan bagi bahasa sumber (BSu) sehingga pesan yang terkandung dalam $\mathrm{BSu}$ dapat diungkap kembali di dalam bahasa sasaran (BSa) dan harus ditempatkan dalam konteks komunikasi, khususnya komunikasi kebahasaan. Menurut Hoed padanan adalah unsur bahasa sasaran yang mengandung pesan yang sama dengan unsur bahasa sumber. Kesepadanan diukur tidak hanya dengan makna unsur bahasa yang bersangkutan, tetapi juga dengan pemahaman suatu hasil terjemahan oleh penerimanya. Sejalan dengan Hoed, Nida mendefinisikan penerjemahan adalah attemps to reproduce equivalence (upaya mereproduksi kesepadanan). Kesepadanan (equivalence) oleh Nida digolongkan ke dalam dua jenis, yaitu:

a. Formal equivalence, atau kesepadanan yang berorientasi pada bahasa sumber untuk menampilkan sebanyak mungkin bentuk dan isi teks asli, jadi sifatnya sedikit banyak literal, dan

b. Dynamical equivalence, yang lebih mengarahkan pada kesepadanan efek terhadap penerima atau kesepadanan pada respon yang diharapkan. Bentuk dapat saja berubah, namun sedapat mungkin setara.

Larson (1984) dalam bukunya Meaning Based Translation: A Guide to Cross-Language Equivalence, mengajurkan pencapaian ekivalensi yang bergerak dari kesepadanan bentuk hingga ke kesepadanan struktur semantik. Menurutnya makna (meaning) harus ditransfer, dan dipertahankan untuk tetap konstan, dengan memerhatikan kesesuaian antara BSu dan BSa pada aspek leksikal, struktur grammatikal, dan fonologis.

\section{- Metode-metode Terjemahan}

Newmark menjelaskan 8 jenis penerjemahan (dalam Hoed, 1993:17-20), diantaranya:

a. Metode penerjemahan kata demi kata (word-for-word translation)

Metode penerjemahan jenis ini biasanya langsung meletakkan kata-kata BSa di bawah versi BSu. Kata-kata dalam BSu diterjemahkan di luar konteks, dan kata-kata yang bersifat kultural (misalnya kata tempe) dipindahkan apa adanya. Umumnya metode ini dipergunakan sebagai tahapan prapenerjemahan (sebagai gloss) pada penerjemahan teks yang sangat sukar.

b. Metode penerjemahan harfiah (literal translation)

Struktur gramatikal $\mathrm{BSu}$ dicarikan padanannya yang terdekat dalam BSa, tetapi penerjemahan leksikalnya dilakukan terpisah dari konteks. Contoh terjemahan yang harfiah adalah penerjemahan kalimat It's raining cats and dogs menjadi Hujan kucing dan anjing dalam bahasa Indonesia. penerjemahan yang lepas konteks semacam ini selain menghasilkan versi BSa yang tak bermakna (kucing dan anjing tidak dapat berjatuhan dari langit), juga menghasikan versi BSa yang tidak hrim Maka seperti halnya metode (1) di atas, dalam proses penerjemahan, metode ini dapat digunakan sebagai kegiatan prapenerjemahan, tidak sebagai metode yang haim. 
c. Metode penerjemahan setia (faithful translation)

Dalam metode ini, penekanan ada pada makna kontekstual BSu. Ada upaya untuk benar-benar setia kepada maksud pengarang asli dan kepada segala perwujudan maksudnya dalam teks $\mathrm{BSu}$. Metode ini sedikit lebih bebas daripada metode (2), tetapi versi BSa-nya masih terasa kaku karena "kesetiaan" tersebut mengabaikan kewajaran penyampaian dalam BSa. Sebagai contoh: penerjemahan kalimat It's raining cats and dogs menjadi Suara hujannya seperti suara kucing dan anjing. Di sini, ada upaya untuk bersetia kepada BSu dengan tetap menggunakan penggambaran metaforik yang sama seperti aslinya.

\section{c. Metode penerjemahan semantik (semantic translation)}

Perbedaan antara metode (3) dan (4) adalah metode (3) lebih kaku dan tidak berkompromi dengan kaidah BSa, sedangakan metode (4) lebih luwes. Sebagai contoh adalah kalimat $\mathrm{He}$ is a book-worm yang diterjemahkan menjadi Dia (laki-laki) adalah orang yang suka sekali membaca. Sekalipun pemadanan tersebut bersifat fungsional (dapat dimengerti dengan mudah), tidak diupayakan adanya pemadanan budaya. Akan lebih idiomatik misalnya, apabila kalimat tersebut diterjemahkan menjadi Dia (laki-laki) adalah seorang kutu buku (padanan adalah kutu). Namun, sekalipun versi yang terdahulu tidak idiomatik dapat menghasilkan terjemahan yang berterima, sehingga dapat menjadi metode penerjemahan yang berterima juga.

Selain melalui penekanan kepada BSu seperti dijelaskan di atas, metode penerjemahan dapat lebih ditekankan kepada kepada BSa. Ini berarti bahwa selain pertimbangan kewacanaan, penerjemahan juga mempertimbangkan hal-hal lain yang berkaitan dengan BSa: (a) siapakah khalayak pembaca versi BSa, misalnya apakah mereka tenaga ahli dalam bidang tertentu ataukah masyarakat umum; (b) tujuan penerjemahan, misalnya untuk tujuan ilmiah, popular, atau demi kesenangan belaka; (c) kewajaran penyampaian, misalnya apakah bahasanya terasa kaku, alami ataukah tidak.

e. Metode saduran (adaptation)

Metode ini merupakan bentuk penerjemahan yang "paling bebas" dan paling dekat dengan BSa. Biasanya metode ini dipakai dalam penerjemahan drama atau puisi, dimana karakter dan plot dipertahankan, tetapi dalam penerjemahannya, terjadi peralihan budaya $\mathrm{BSu}$ ke budaya $\mathrm{BSa}$, dan teks aslinya ditulis kembali serta diadaptasikan ke dalam BSa.

f. Metode penerjemahan bebas (free translation)

Metode ini merupakan penerjemahan yang mengutamakan isi dan mengorbankan bentuk teks BSu. Biasanya, metode ini berbentuk suatu parafrase, yang dapat lebih panjang ataupun lebih pendek dari aslinya. Metode ini sering dipakai oleh mereka di kalangan media massa. Suharno menyebutnya metode "oplosan" (Hoed, 1993:19).

g. Metode penerjemahan idiomatis (idiomatic translation)

Metode ini bertujuan mereproduksi pesan dalam teks $\mathrm{BSu}$, tetapi sering dengan menggunakan kesan keakraban dan ungkapan idiomatik yang tidak didapat pada versi aslinya. Dengan demikian, banyak terjadi distorsi nuansa makna.

h. Metode penerjemahan komunikatif (communicative translation)

Metode in mengupayakan reproduksi makna kontekstual yang sedemikian rupa sehingga, baik aspek kebahasaan maupun aspek isinya langsung dapat dimengerti oleh pembaca. Maka, versi BSa-nya pun langsung berterima. Sesuai dengan namanya, metode ini memperhatikan prinsip- 
prinsip komunikasi, yaitu khalayak pembaca dan tujuan penerjemahan. Maka, melalui metode ini, suatu versi $\mathrm{BSu}$ dapat diterjemahkan menjadi beberapa versi $\mathrm{BSa}$ (dalam Hoed, 1993:20).

\section{PENERJEMAHAN METAFORA DALAM SAMAN KE DALAM BAHASA PRANCIS}

Berdasarkan hasil pengolahan data, ditemukan 4 kategori sesuai dengan teori Stephen Ullman, yaitu:

\section{Antromorphic Metaphors}

Penerjemahan Anthromorphic Metaphors ini dapat dilihat pada data berikut :

BSu : Di mulut jalan Kapiten Patimura mobil distop (h.176)

BSa : ...dans la rue Kapitan Patimura, notre voiture est arrêtée. (p.230)

Makna metafora "mulut jalan" adalah bagian awal atau ujung dari jalan. Makna dari kata "mulut" sendiri adalah rongga di muka, tempat gigi dan lidah, untuk memasukkan makanan. Metafora "mulut jalan" ini dibentuk dengan mengibaratkan sebuah bagian jalan yang terletak di muka atau di bagian depan, tempat keluar masuknya kendaraan.

- dans = di

- la rue = jalan

Metafora pada BSu di atas diterjemahkan ke BSa menjadi dans la rue yang memiliki arti "di jalan". Di sini terjadi perubahan bentuk, dari yang khusus ke bentuk yang umum. Sebenarnya bahasa Prancis juga mengenal metafora "mulut jalan" dengan istilah l'entrée de rue. Dilihat dari konteks kalimatnya tercermin perbedaan kebiasaan dari kedua negara. Seperti yang diketahui bersama bahwa biasanya polisi di Indonesia berjaga di ujung-ujung jalan, berbeda dengan polisi di Prancis, sehingga muncul anekdot, bahwa polisi Indonesia sengaja bersembunyi di ujung jalan untuk memergoki pengendara yang melanggar. Dari penjelasan di atas dapat disimpulkan bahwa penerjemah menggunakan metode penerjemahan bebas dan teknik penerjemahan generalisasi.

Data berikut juga memperlihatkan penerjemahan Anthromorphic Metaphors:

$\mathrm{BSu}$ : Ia seperti kota gurun yang terkepung, mata airnya telah dikuasai musuh (h.93)

$\mathrm{BSa}$ : Il était comme une citadelle $d u$ désert assiégée, ses puits déjà sous contrôle de l'ennemi. (p.127)

Metafora "mata air" pada BSu memiliki makna leksikal : tempat air yang mengalir dari batuan atau tanah ke permukaan tanah secara alamiah; sumber air. Kalimat BSu tersebut diterjemahkan menjadi kata "puits" yang berarti sumur.

- ses = nya

- puits = sumur-sumur

Puit(s) merupakan nomina dalam bahasa Prancis yang mempunyai arti "sumur" dalam bahasa Indonesia. Penambahan "ses" yang merupakan adjectif possesif untuk orang ketiga jamak bertujuan untuk menerangkan kepunyaan dari nomina (puits), yang dapat diartikan dengan “nya".

Sumur di sini memiliki makna leksikal sumber air buatan yang diperoleh dengan cara menggali tanah. Walaupun sumur juga merupakan sumber air tapi hanya buatan, lain halnya dengan mata air yang terbentuk secara alamiah. Di sini juga terlihat adanya perubahan bentuk, dari kalimat $\mathrm{BSu}$ yang memiliki nomina tunggal ke kalimat BSa yang berbentuk jamak. 
Sebenarnya bahasa Perancis juga mengenal istilah "mata air", yaitu : la source. Dalam bahasa Prancis puit adalah cavite circulaire, profonde et étroite, à paroi maçonnees, praquée dans le sol pour atteindre une nappe d'eau (lubang bundar, dalam dan sempit, bagian dalam tembok, membuat lubang dalam tanah untuk mencapai lapisan air). Sedangkan la source adalah eau qui sort de terre (air yang keluar dari tanah). Melihat penjelasan di atas sangat terlihat jelas perbedaan dari kedua kata di atas.

Dengan melihat pembahasan di atas disimpulkan bahwa penerjemah menggunakan metode penerjemahan bebas untuk menerjemahkan kalimat $\mathrm{BSu}$ di atas. Dari segi bentuk, metafora Indonesia pada data ini tidak diterjemahkan kembali ke bentuk metafora dalam bahasa Prancis, dan ini merupakan kelalaian dalam penerjemahan.

\section{Animal Metaphors}

Model penerjemahan

Metaphors terjadi pada contoh berikut

BSu: « Teror pun mulai hinggap di dusun itu «. (p.93) BSa: Mais la terreur gagnait leur village. (p.127)

Makna dari metafora "teror pun mulai hinggap di dusun itu" adalah : " dusun tersebut mulai merasakan teror ». Kalimat $\mathrm{BSu}$ tersebut diterjemahkan menjadi "mais la terreur gagnait leur village" dalam $\mathrm{BSa}$.

$$
\begin{array}{ll}
\text { - } \text { mais } & =\text { tetapi } \\
\text { - } \text { la terreur } & =\text { teror } \\
\text { - } \text { gagnait } & =\text { mendapat } \\
\text { - leur } & =- \text { nya } \\
\text { - Village } & =\text { desa }
\end{array}
$$

Mais merupakan konjungsi dalam bahasa Prancis yang mempunyai arti "akan tetapi", "tetapi" atau "tapi". $\quad L a$ terreur,merupakan nomina dalam bahasa
Prancis yang mempunyai arti "rasa takut sekali", "ketakutan yang sangat (sampai lemas)" atau "teror". Penambahan article défini "la" menandakan nomina tersebut berjenis feminin. Gagnait berasal dari kata gagner merupakan verba dalam bahasa Prancis yang telah dikonjugasikan dalam bentuk imparfait untuk orang ketiga tunggal. Verba tersebut mempunyai arti "mendapat" atau "memperoleh (keuntungan material)" dalam bahasa Indonesia. Leur merupakan adjektif possessif untuk orang ketiga jamak dalam bahasa Prancis yang dalam bahasa indonesia diartikan dengan kata "...nya". Village merupakan nomina dalam bahasa Prancis yang dalam bahasa Indonesia berarti "desa" atau "kampung". Jika kalimat BSu tersebut diterjemahkan kata per kata maka artinya adalah "tapi teror mendapat desa mereka". Di sini terjadi pergeseran makna, perbedaan nuansa atau bahkan kuantitas antra kalimat BSu danBSa. Kalimat BSu memberi kesan lebih halus dengan menggunakan kata "hinggap" yang bermakna 《 bertengger » setelah terbang (tentang burung), teror itu seolah-olah baru akan dimulai. Lain halnya dengan kalimat BSa yang menggunakan kata gagnait (gagner) yang memberi kesan seolah-olah teror itu telah lama terjadi di desa itu (mendapatkannya). Kata dusun pun diartikan menjadi village yang mempunyai arti "kampung" atau "desa". Dengan melihat pembahasan di atas ditarik kesimpulan bahwa penerjemah menggunakan metode penerjemahan bebas dan teknik penerjemahan lazim. Dari segi bentuk, metafora bahasa Indonesia pada data di atas diterjemahkan kembali dengan bentuk metafora dalam bahasa Prancis. Hal tersebut dimaksudkan untuk mempertahankan bentuk atau makna metafora yang ada pada BSu.

Data lain yang memperlihatkan penerjemahan Animal Metaphors terdapat pada data berikut: 
BSu: Musim dingin sudah merayap. (p.140). BSa : L'hiver était déjà bien avancé. (p.184)

Makna metafora "musim dingin sudah merayap" adalah musim dingin sudah mulai terasa. Kalimat $\mathrm{BSu}$ tersebut diterjemahkan menjadi 'I'hiver était déjà bien avancé" dalam Bsa.

- l'hiver = :musim dingin

- était = adalah

- déjà = sudah

- bien avancé = berlangsung

L'hiver merupakan nomina dalam bahasa Prancis yang mempunyai arti "musim dingin". Penambahan article defini ' $\mathrm{l}$ atau le" menandakan bahwa nomina tersebut mempunyai genre maskulin. Était berasal dari kata être yang merupakan verba dalam bahasa Prancis yang telah dikonjugasikan ke dalam bentuk imparfait untuk orang ketiga tunggal yang artinya "adalah".

Déjà merupakan adverbe de temps (kata keterangan waktu) dalam bahasa Prancis, yang mempunyai arti "sudah".

Bien avancé terbentuk dari dua kata yaitu bien yang merupakan adjektiva yang berarti "baik"; dan avancé yang juga adjektiva yang berarti "(waktu) jauh" dalam bahasa Indonesia. Jika digabungkan, kedua kata tersebut membentuk kata yang berarti "berlangsung".

Jika di terjemahkan dalam BSa maka arti dari kalimat BSa tersebut adalah, "musim dingin sudah berlangsung". Di sini terlihat terjadi pergeseran makna antara $\mathrm{BSu}$ dan BSa. Kata "merayap" yang mempunyai makna bergerak perlahan-lahan diterjemhakan menjadi "bien avancé" yang berarti 'berlangsung". Dari penjelasan di atas maka disimpulkan bahwa untuk menerjemahkan kalimat $\mathrm{BSu}$ di atas penerjemah menggunakan metode penerjemahan bebas.

Dari segi bentuknya, metafora bahasa Indonesia dalam data di atas tidak diterjemahkan kembali ke dalam bentuk metafora bahasa Prancis. Ini dikarenakan kosakata tersebut tidak dikenal dalam bahasa Prancis.

\section{From Concrete to Abstract}

$\mathrm{BSu}$ : Namun, sepotong langit mampir lewat jendela sebagai kejutan yang segar. (p.74)

BSa : Un morceau de ciel, cependant, se présentait à travers la fenêtre telle une heureuse suprise. (p.105)

Makna dari metafora "namun, sepotong langit mampir lewat jendela" adalah malam sudah terlihat melalui jendela. Kalimat BSa tersebut diterjemahkan ke dalam BSu menjadi "un morceau de ciel, cependant, se présentait à travers la fenêtre".

- un morceau = sepotong

- de ciel = langit

- cependant = namun

- se présentait = muncul

- a travers = datang

- la fenêtre = jendela

Morceau merupakan nomina dalam bahasa Prancis yang artinya "bagian", "penggal" atau "potong" dalam bahasa Indonesia. Penamabahan article indefini "un" menekankan kuantitas.

Ciel, merupakan nomina dalam bahasa Prancis yang berarti "langit", sedangkan de adalah article partitif yang dapat diartikan "dari" dalam bahasa Indonesia.

Cependent merupakan konjungsi dalam bahasa Prancis yang memiliki arti "meskipun demikian", "namun 


\section{3 | JURNAL ILMU BUDAYA}

Volume 6, Nomor 1, Juni 2018 (demikian)", 'biar begitu", “toh", atau 'tetapi”.

Se présentait adalah verba pronomina dalam bahasa Prancis yang dikonjugasikan dalam bentuk imparfait untuk orang ketiga tunggal, berasal dari kata se présenter yang mempunyai arti, "(datang) menghadap", "menemui (seseorang)", "memperkenalkan diri", atau "muncul".

À travers merupakan preposisi dalam bahasa Prancis yang terbentuk dari preposisi $a$ dan nomina travers yang bila disatukan mempunyai arti "melalui", "melintas" atau "lewat di tengah".

La fenêtre, merupakan nomina yang berasal dari bahasa Prancis yang berarti "jendela". Penambahan article "la" menandakan bahwa kata fenêtre mempunyai jenis feminin.

Jika di terjemahkan secara kata per kata maka arti dari BSa tersebut adalah, "sepotong langit, namun, datang melalui jendela".

Dalam segi bentuk, metafora bahasa Indonesia dalam data di atas diterjemahkan kembali ke bentuk metafora dalam bahasa Prancis. Hal tersebut dimaksudkan untuk mempertahankan bentuk atau makna metafora yang ada pada BSu.

Model penerjemahan from concrete to abstract juga dapat dilihat pada contoh berikut:

$\mathrm{BSu}:$ Musim hujan telah datang, seperti berlari-lari dari timur lalu mengguyur perkebunan. (p.81)

$\mathrm{BSa}:$ Lamousson ét a it arrivée en courant de l'est, puis elle trempé la plantation. (p.112)

Pada metafora "musim hujan telah datang, seperti berlari-lari dari timur", musim hujan digambarkan berlari seperti manusia. Kalimat $\mathrm{BSu}$ tersebut diterjemahkan menjadi la mousson était arrivée en courant de l'est.
- la mousson = angin musim

- était arrivée = telah tiba

- en courant = sambil berlari

- de = dari

- l'est = Timur

La mousson merupakan nomina dalam bahasa Prancis yang mempunyai artinya "angin musim" dalam bahasa Indonesia. Penambahan article "la" menandakan bahwa nomina tersebut berjenis feminin.

Était arrivée merupakan verba yang berasal dari kata arriver yang mempunyai arti "tiba". Verba tersebut dikonjugasikan dalam plus-que-parfait (sujet + aux avoir/être (imparfait) + partisip passé).

En courant merupakan gérondif dalam bahasa Prancis yang terbentuk dari adverbia en + adjektiva courant yang berarti "sambil berlari" dalam bahasa Indonesia."De" merupakan preposisi dalam bahasa Prancis yang dapat diartikan "dari" dalam bahasa Indonesia.

L'est sebenarnya berasal dari "le" + "est" yang mempunyai arti "timur", penambahan article "le" menegaskan bahwa kata itu mempunyai jenis maskulin. Penulisannya digabung karena dalam bahasa Prancis jika ada huruf vokal bertemu dengan huruf vokal maka penulisannya digabung dengan menggunakan tanda petik, salah satu huruf vokalnya pun di hilangkan dan pengucapannya bersambung. Jika diterjemahkan kata per kata maka arti kalimat BSa tersebut adalah "angin musim telah datang dengan berlari dari timur". Dilihat dari strukturnya, penerjemah menggunakan metode penerjemahan setia dan teknik penerjemahan kalke dalam menerjemahkan kalimat $\mathrm{BSu}$ di atas. Namun, yang berbeda di sini adalah penggalan kalimat "musim hujan" diartikan menjadi la mousson, yang berarti "angin musim" dalam BSu. Dalam BSa "musim hujan" dikenal dengan saison des pluies. Sedangkan jika dilihat dari segi 
bentuk, metafora bahasa Indonesia pada data tersebut diterjemahkan kembali ke bentuk metafora dalam bahasa Prancis. Hal tersebut dimaksudkan untuk mempertahankan bentuk atau makna metafora yang ada pada BSu.

\section{- Synaesthetic Metaphors}

$\mathrm{BSu}$ : Wis mendengar raungan yang menyayat ketika dua lelaki tadi menggembok rantai pintu. (p.70)

BSa : Wis entendit ses geignements déchirants lorsque les deux hommes cadenassèrent la porte. (p.100)

Makna dari metafora "raungan yang menyayat" adalah teriakan yang menyedihkan. Kata "meraung" sendiri memiliki arti berbunyi nyaring dan panjang. Kata meraung sendiri biasanya digunakan untuk hewan, misalnya harimau, srigala atau anjing. Kalimat BSu di atas diterjemahkan menjadi ses geignements déchirants dalam BSa.

- $\quad$ ses geignements = merengeknya

- déchirants = menyayat

Kata "raungan" pada BSu diterjemahkan menjadi geignement(s) yang merupakan ajektiva dalam bahasa Prancis yang mempunyai arti merengek dalam BSa. Merengek sendiri memiliki makna meminta sesuatu dengan mendesak (sambil menangis-nangis kecil). Terlihat terjadi perubahan makna antara $\mathrm{BSu}$ dan $\mathrm{BSa}$, kalimat $\mathrm{BSu}$ terkesan lebih garang dengan menggunakan kata "raungan" sedangkan kalimat BSa terkesan menampilkan kesan lebih manja dengan menggunakan kata geignement(s) yang mempunyai arti "merengek" dalam bahasa Indonesia.

Déchirants merupakan ajektiva yang berasal dari verba déchirer berbentuk jamak dalam bahasa Prancis yang mempunyai arti "mengiris", "menguliti" atau "menyedihkan" dalam bahasa Indonesia.
Dengan melihat penjabaran di atas, dapat disimpulkan bahwa penerjemah menggunakan metode penerjemahan bebas dan teknik penerjemahan lazim dalam menerjemahkan kalimat $\mathrm{BSu}$ di atas. Dilihat dari segi bentuk, metafora bahasa Indonesia dalam kasus di atas diterjemahkan kembali ke dalam bentuk metafora dalam bahasa Prancis. Hal tersebut dimaksudkan untuk mempertahankan bentuk atau makna metafora yang ada pada BSu.

$\mathrm{BSa}$ : Setelah semua murid berbaris masuk, kepala sekolah memutar tuas hingga gerbang menutup dengan bunyi dentum yang menerbangkan rambut. (p.119)

$\mathrm{BSu}:$ Une fois tous les élèves rentrés en rangs, le directeur de l'école tournait le levier jusqu'à ce que la porte se ferme dans une détonation qui faisait s'envoler les cheveux. (p.159)

Makna dari metafora "bunyi dentum yang menerbangkan rambut" menggambarkan bahwa bunyi dentum itu sangat keras hingga getaran dari bunyi tersebut dapat menerbangkan rambut. Kalimat BSu tersebut diterjemahkan menjadi une détonation qui faisait s'envoler les cheveux dalam BSa.

- une détonation = bunyi dentum

- $q u i \quad=$ yang

- faisait s'envoler = menerbangkan

- les cheveux = rambutnya

Une détonation merupakan nomina dalam bahasa Prancis dengan jenis feminin yang mempunyai arti "ledakan", "letusan" atau "dentuman".

Qui merupakan pronom relatif sujet dalam bahasa Prancis yang dalam bahasa Indonesia berarti "yang".

Faisait s'envoler berasal darifaire envoler yang telah dikonjugasikan ke dalam 
bentuk imparfait untuk orang ketiga tunggal. Faire envoler dalam bahasa Indonesia mempunyai arti "membuat terbang" atau "menerbangkan".

Les cheveux, merupakan nomina dalam bahasa Prancis dengan bentuk jamak, yang artinya "rambut" dalam bahasa Indonesia.

Dari uraian di atas dapat disimpulkan bahwa untuk menerjemahkan kalimat di atas penerjemah menggunakan metode penerjemahan harfiah dan teknik penerjemahan kalk. Dari segi bentuk, metafora bahasa Indonesia dalam data di atas kembali diterjemahkan ke bentuk metafora dalam bahasa Prancis. Hal tersebut dimaksudkan untuk mempertahankan bentuk atau makna metafora yang ada pada BSu.

\section{KESIMPULAN}

Berdasarkan hasil analisis penerjemahan metafora dari bahasa Indonesia ke bahasa Prancis dapat ditarik kesimpulan sebagai berikut:

Persamaan pola pembentukan kalimat antara $\mathrm{BSu}$ (bahasa Indonesia) dengan BSa (bahasa Prancis), yaitu MD (menerangkan-diterangkan), serta sifat asosiasi makna yang cenderung umum, mengakibatkan beberapa metafora diterjemahkan kembali ke dalam bentuk metafora yang setara secara struktural maupun leksikal. Beberapa faktor yang mengakibatkan sebagian metafora tidak diterjemahkan kembali ke dalam bentuk metafora, yaitu: Sistem linguistik yang berbeda. Sistem linguistik pada bahasa Indonesia adalah aglutinatif, yaitu bahasa yang pembentukan katanya melalui proses pengibuhan, sedangkan bahasa Prancis menganut sistem flektif, yaitu bahasa yang kata-katanya mengalami perubahan bentuk sehubungan dengan perubahan jenis, subjek (pelaku), waktu, dsb. Pola pikir yang berbeda, karena budaya yang berbeda, yang antara lain disebabkan berbedanya system linguistik yang dianut oleh kedua bangsa tersebut, juga menjadi sebab sulitnya beberapa beberapa metafora diterjemahkan kembali ke dalam gaya yang sama.

\section{DAFTAR PUSTAKA}

Anwar, Stevany M. 2008. Metafora Bahasa Prancis dan Padanannya dalam Pribahasa Indonesia (Suatu Tinjauan Semantik). Skripsi S1Universitas Hasanuddin. Makassar. Glueck, Helmut. 1993. Metzler Lexikon Sprache. Metzle Verlag: Stuttgart, Weimer.

Hoed, Benny Hoedoro. 1993. Pengetahuan Dasar Tentang Penerjemahan.

Jakarta: Lintas Bahasa

Labrousse, Pierre. 2009. Kamus Umum Indonesia-Prancis. Jakarta: Penerbit PT Gramedia Pustaka Utama.

Hasyim, Muhammad. 2017. The Metaphor of Consumerism. Journal of Language Teaching and Research. Vol. 8, No. 3, pp. 523-530, May 2017.

Parera, JD. 2004. Teori Semantik. Jakarta: Penerbit Erlangga.

Sastriyani, Siti Hariti. 2011. Sastra Terjemahan Prancis-Indonesia. Yogyakarta: Gadjah Mada University Press

Tarigan, Henry Guntur. 2009. Pengajaran Gaya Bahasa. Bandung: Penerbit Angkasa.

Utami, Ayu. 2002. Saman. Jakarta: KPG (Kepustakaan Populer Gramedia) bekerjasama dengan Jurnal Kebudayaan Kalam. Utami, Ayu. 2008. Saman. Prancis: Flammarion.

Wahyuddin. 2012. Fungsi Metafora Dalam Pengungkapan Realitas (Kajian Filsafat Bahasa Paul Ricoeur) dalam seminar triwulan, Jurusan Sastra Prancis Unhas. 